\title{
Inclusion of L-Alanine, L-Arginine, L-Aspargine, L-Serine and Proline into $\theta$-Type Zirconium Phosphate
}

\author{
Sadek Shakshooki, Abdurrahman Rhuma, and Fadel Siala
}

\begin{abstract}
Layered $\theta$-Type zirconium phosphate $\left(\theta-\mathrm{Zr}\left(\mathrm{HPO}_{4}\right)_{2} \cdot 1.88 \mathrm{H}_{2} \mathrm{O}\right)$ was prepared by the reaction of zirconium oxychloride in $\mathrm{HF}$ solution with dilute $\mathrm{H}_{3} \mathrm{PO}_{4}$ at $15^{\circ} \mathrm{C}$. The resulting compound was intercalated with amino acids L-alanine, L-arginine, L-aspargine, L-serine and proline respectively at room and $600 \mathrm{C}$ temperatures. The structure properties of the obtained products were characterized by fourier transform infrared spectroscopy (FT-IR), X-ray powder diffraction (XRD) and thermal analysis (TG/DTA). FT-IR spectrum results demonstrated that the effectiveness of the vibrational spectra in characterizing of the resultant product was supported by TG/DTA and X-ray analysis. Moreover, the vibrational spectroscopic investigation shows that water molecules were appeared very characteristic infrared bands that can be assigned to regular hydrogen bonding of each molecule to adjacent $\mathrm{OH}$ group of (POH). Furthermore, amino acids inclusion products were found to retain the layered structure and the loading are closely dependent on the nature of the amino acid.
\end{abstract}

Index Terms-Inclusion, amino acids, 0-type zirconium phosphate.

\section{INTRODUCTION}

Tetravalent metal phosphates are very insoluble compounds which were known as amorphous for some time [1], [2]. The discovery of their crystalline layered structure by Clearfield and Stynes in 1964 [3] represents the fundamental step in the chemistry of these compounds and found to be $\alpha$-layer of type. Their layered crystalline materials resemblance clay minerals [4].The layered materials receiving great attention because of their size, structure, and possible biochemical applications [5] that have been proven to be good carriers for organic polar molecules. Examples of these are zirconium phosphates [4] taking advantage of the expandable interlayer space of the layered materials. Researchers have been capable of encapsulating functional biomolecules into these inorganic matrices protecting them from interacting with environment, avoiding denaturation and enhancing their shelf [4]-[6].

Porous layered $\mathrm{M}^{\mathrm{IV}}$ phosphates with $\alpha, \theta$ and $\gamma$-structures [7]-[9]. $\alpha-\mathrm{M}^{\mathrm{IV}}\left(\mathrm{HPO}_{4}\right)_{2} \cdot \mathrm{H}_{2} \mathrm{O}, \theta-\mathrm{M}^{\mathrm{IV}}\left(\mathrm{HPO}_{4}\right)_{2} \cdot 5 \mathrm{H}_{2} \mathrm{O}$ and $\gamma-\mathrm{M}^{\mathrm{IV}}$. $\mathrm{PO}_{4} \cdot \mathrm{H}_{2} \mathrm{PO}_{4} \cdot 2 \mathrm{H}_{2} \mathrm{O}$ are well known compounds, (where $\mathrm{M}=\mathrm{Ti}$, $\mathrm{Zr}, \mathrm{Hf}, \mathrm{Sn}, \mathrm{Ce})$. These materials contain structural $\mathrm{POH}$

Manuscript received September 9, 2013; revised February 11, 2014. This work was supported in part by the Department of Chemistry, Faculty of Science, University of Tripoli, Industrial Research Centre, Tripoli, Libya and Adel Bayoumi, the Institute of Mineral Resources, Cairo, Egypt.

The authors are with the Department of Chemistry, Faculty of Science, University of Tripoli, UK (e-mail: shakshooki2002@yahoo.com, Rahuma1@hotmail.com). groups with labile protons and therefore potential candidates as Intercalates [10], ionic co-conductance materials [11], solid acid catalysts [12] and sensors [13].

$\theta$-zirconium phosphate, $\mathrm{Zr}\left(\mathrm{HPO}_{4}\right)_{2} .5 \mathrm{H}_{2} \mathrm{O}$, has an interlayer spacing of $10.4 \AA$ is readily prepared from protonation of its parent monosodium form $\mathrm{Zr}\left(\mathrm{NaPO}_{4}\right)\left(\mathrm{PO}_{4}\right) .5 \mathrm{H}_{2} \mathrm{O}$ or from hydration of the metastable alcohol form $\mathrm{Zr}\left(\mathrm{HPO}_{4}\right)_{2}$. $\left(\mathrm{C}_{2} \mathrm{H}_{5} \mathrm{OH}\right)_{2}$ [1], [14]. $\theta$-zirconium phosphate $\mathrm{Zr}\left(\mathrm{HPO}_{4}\right)_{2} .5 \mathrm{H}_{2} \mathrm{O}$, has a tendency to exchange large size metal ions, such as $\mathrm{Cs}^{+}, \mathrm{Mg}^{2+}, \mathrm{Ba}^{2+}$, divalent and trivalent transition metal ions and to intercalate bulky amines [1], [8].

Amino acids are biologically important organic compounds made from amine $\left(-\mathrm{NH}_{2}\right)$ and carboxylic acid $(-\mathrm{COOH})$ functional groups, along with a side-chain specific to each amino acid. The key elements of an amino acid are carbon, hydrogen, oxygen, and nitrogen, though other elements are found in the side-chains of certain amino acids.

To date only few reports on intercalation of amino acids into $\alpha$, or $\gamma$ - layered $\mathrm{M}^{\mathrm{IV}}$ phosphates [15]-[18] are available. In this study the synthesis and characterization of novel $\theta$-type zirconium phosphate amino acids intercalated products were investigated.

\section{MATERIALS AND METHODS}

\section{A. Chemicals}

$\mathrm{ZrOCl}_{2} .8 \mathrm{H}_{2} \mathrm{O}, \mathrm{H}_{3} \mathrm{PO}_{4}(85 \%)$ and amino acids L- Alanine $\mathrm{C}_{3} \mathrm{H}_{4} \mathrm{NO}$, L-Asparagine $\mathrm{C}_{4} \mathrm{H}_{8} \mathrm{~N}_{2} \mathrm{O}_{3}$, L-Proline $\mathrm{C}_{5} \mathrm{H}_{9} \mathrm{NO}_{2}$, L-Serine $\mathrm{C}_{3} \mathrm{H}_{5} \mathrm{O}_{3} \mathrm{~N}$ and L-Lysine $\mathrm{C}_{6} \mathrm{H}_{14} \mathrm{~N}_{2} \mathrm{O}_{2}$ used are of $\mathrm{BDH}$, hydrofluoric acid HF (40\%) of Reidel De-Haen. Other reagents used were of analytical grade.

\section{B. Instruments Used for Characterization}

X-Ray powder diffractometer Siemens D-500 was applied by using Ni-filtered $\mathrm{CuK}_{\alpha}(\lambda=1.54056 \AA$. TG/DTA SII Extra 6000 Thermogram and TG/DTA Perkin-Elmer SII were used to identify the thermal behavior of the obtained compounds. Forier Transform FT-IR spectrometer was carried on FT/IR-600. All obtained spectra were measured within a spectral range of 4000-400 $\mathrm{cm}^{1}$. pH Meter WGW 521 were also used in this study to estimate the ion exchange properties of $\theta-\mathrm{Zr}\left(\mathrm{HPO}_{4}\right)_{2} .1 .88 \mathrm{H}_{2} \mathrm{O}$. The investigation of $\mathrm{C}, \mathrm{H}$ and $\mathrm{N}$ contents were analyzed with GMBH Vario Elemental Analyzer.

\section{Preparation of $\theta-\mathrm{Zr}\left(\mathrm{HPO}_{4}\right)_{2} \cdot 1.88 \mathrm{H}_{2} \mathrm{O}$}

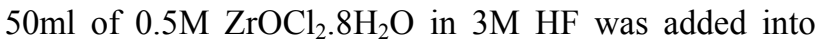
Pyrex round bottom flask containing $200 \mathrm{ml}$ of $(4.6 \mathrm{M}) \mathrm{H}_{3} \mathrm{PO}_{4}$ (prior to mixing, the solutions were cooled at $\sim 15^{\circ} \mathrm{C}$ ). The 
mixture prepared was kept under constant magnetic stirring at $\sim 15^{\circ} \mathrm{C}$ for 3 days. The resultant precipitate was then washed with distilled water by addition and decantation of distilled water in order to obtain the $\mathrm{pH} 3$ of the solution, then filtered and dried in the air.

\section{Exchange Capacity Determination}

Exchange capacity was determined by addition of $25 \mathrm{ml}$ of $0.10 \mathrm{M} \mathrm{NaCl}$ solution to $100 \mathrm{mg}$ of the $\theta-\mathrm{Zr}\left(\mathrm{HPO}_{4}\right)_{2} \cdot 1.88 \mathrm{H}_{2} \mathrm{O}$, with constant continuous stirring for $24 \mathrm{~h}$, then titrated with $0.10 \mathrm{M}$ of $\mathrm{NaOH}$ solution.

\section{E. Inclusion of Amino Acids}

Inclusion procedure was performed by addition of $0.1 \mathrm{M}$ aqueous solutions of amino acids L-alanine, L-arginine, L-serine, L-lysine, L-aspargine and proline, respectively, into $\theta-\mathrm{Zr}\left(\mathrm{HPO}_{4}\right)_{2} \cdot 1.88 \mathrm{H}_{2} \mathrm{O}$.

Typically; to $0.25 \mathrm{~g}$ of $\theta-\mathrm{Zr}\left(\mathrm{HPO}_{4}\right)_{2} .1 .88 \mathrm{H}_{2} \mathrm{O}, 20 \mathrm{ml}$ of $0.1 \mathrm{M} \mathrm{L}$-serine were added at room temperature $\sim 25^{\circ} \mathrm{C}$ and kept for $72 \mathrm{~h}$ with constant continuous stirring. In order to obtain the best intercalation condition for this guest molecule (same reaction repeated at $60^{\circ} \mathrm{C}$ for $5 \mathrm{~h}$ ). The resultant product was filtered, washed with distilled water and dried in the air. Similar intercalation procedure was carried out with L-alanine, L-arginine, L-aspargine and proline. The products were designed as comounds I-V.

\section{RESULTS AND DISCUSSION}

$\theta$-type zirconium phosphate, $\theta-\mathrm{Zr}\left(\mathrm{HPO}_{4}\right)_{2} \cdot 1.88 \mathrm{H}_{2} \mathrm{O}$, was prepared and characterized by chemical, X-ray, thermal analysis and by FT-IR spectroscopy. The exchange capacity was determined by $\mathrm{Na}^{+}$ions titration.

\section{A. XRD Pattern of $\theta-\mathrm{Zr}\left(\mathrm{HPO}_{4}\right)_{2} \cdot 1.88 \mathrm{H}_{2} \mathrm{O}$}

Data presented in Fig. 1 shows the X-ray powder diffraction pattern of the $\theta$-type $\mathrm{Zr}\left(\mathrm{HPO}_{4}\right)_{2} .1 .88 \mathrm{H}_{2} \mathrm{O}$, exhibit the presence of diffraction maxima with basal spacing equal to $9.85 \AA$ and also exhibit lamellar structure. Negatively charged layers are formed by macroanions $\left[\mathrm{M}_{\mathrm{n}}(\mathrm{IV})\right.$ $\left.\left(\mathrm{HPO}_{4}\right)_{2 \mathrm{n}}\right]^{-2 \mathrm{n}}$ and protons $\left(\mathrm{H}^{+}\right)$bonded to the oxygen adjacent to the anionic layer form positively charged layers. However, the water molecules occupying crystallographic sites are located almost in the center of interlayer cavities.

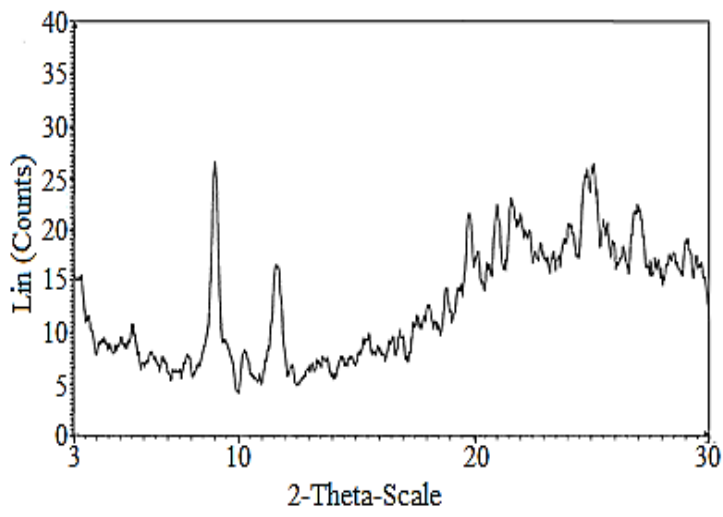

Fig. 1. X-ray diffractogram of $\theta-\mathrm{Zr}\left(\mathrm{HPO}_{4}\right)_{2} \cdot 1.88 \mathrm{H}_{2} \mathrm{O}$.

\section{B. FT-IR Spectra of the $\mathrm{\theta}-\mathrm{Zr}\left(\mathrm{HPO}_{4}\right)_{2} \cdot 1.88 \mathrm{H}_{2} \mathrm{O}$}

FT-IR becomes a key tool to investigate structure. Fig. 2 show FT-IR spectra of $\theta-\mathrm{Zr}\left(\mathrm{HPO}_{4}\right)_{2} \cdot 1.88 \mathrm{H}_{2} \mathrm{O}$ in the range $4000-400 \mathrm{~cm}^{-1}$ wave number.

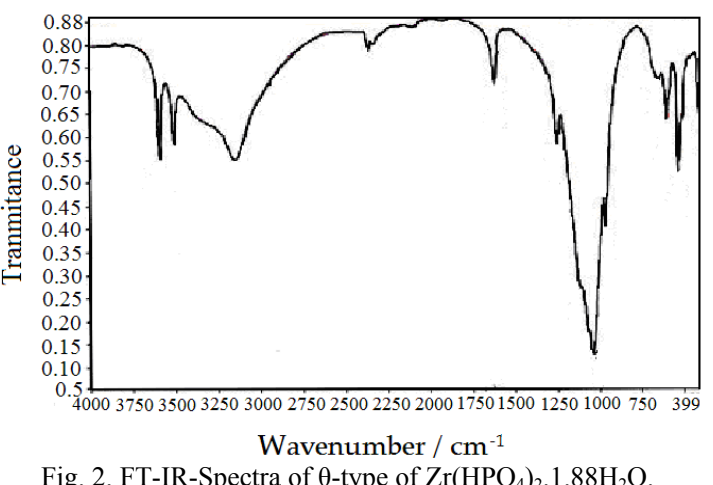

A tentative assignment of various vibrational 3 modes is proposed based on previous works preformed in other M(IV) phosphate compounds [18].

The FT-IR spectra of $\theta-\mathrm{Zr}\left(\mathrm{HPO}_{4}\right)_{2} \cdot 1.88 \mathrm{H}_{2} \mathrm{O}$ show the same trend of modes. From Fig. 2, the narrow bands at $3604.65 \mathrm{~cm}^{-1}, 3434.11$ and band at $1640.39 \mathrm{~cm}^{-1}$ are assigned to vibrational modes of $\mathrm{H}_{2} \mathrm{O}$ molecules suggest that water molecules are located at well defined crystallographic sites. These bands at $3604.65 \mathrm{~cm}^{-1}$ and $3434.11 \mathrm{~cm}^{-1}$ were also attributed to an $\mathrm{O}-\mathrm{H}$ asymmetric modes of interlayer water molecules. The band at $1640.39 \mathrm{~cm}^{-1}$ also corresponds to $\mathrm{H}-\mathrm{O}-\mathrm{H}$ bending modes and the broad band at $3147.10 \mathrm{~cm}^{-1}$ assigned to $(\mathrm{P}) \mathrm{OH}$ stretching mode of the hydrogen bond, it had shoulder at $3310 \mathrm{~cm}^{-1}$ attributed to $\mathrm{O}-\mathrm{H}$ stretching coming from symmetry lowering effect of the $\mathrm{H}_{2} \mathrm{O}$ interlayer molecules.

At the region $1273.21-1054.46 \mathrm{~cm}^{-1}$, the bands are assigned as $\mathrm{P}-\mathrm{O}$ asymmetry stretching of $\mathrm{PO}_{4}$ groups, while at $976.33 \mathrm{~cm}^{-1}$ is characteristic to the bonding in plane of the (P-O) bond.

In the region $609.14-515.39 \mathrm{~cm}^{-1}$, the bands ascribed to the presence of $\delta\left(\mathrm{PO}_{4}\right)$ and to vibrational of water molecules $\left(609.14 \mathrm{~cm}^{-1}\right)$, while at $671.64 \mathrm{~cm}^{-1}$ is connected with $\mathrm{O}-\mathrm{H}$ bond (out of plane).

\section{Exchange Capacity}

Exchange capacity of $\theta-\mathrm{Zr}\left(\mathrm{HPO}_{4}\right)_{2} \cdot 1.88 \mathrm{H}_{2} \mathrm{O}$ was determined by $\mathrm{Na}^{+}$ions titration. The titration curve is shown in Fig. 3. The exchange capacity found to be equal to $6.2 \mathrm{Meq} / \mathrm{g}$. The calculated value is $6.01 \mathrm{Meq} / \mathrm{g}$. This difference is due to partial hydrolysis of $\mathrm{HPO}_{4}{ }^{2-}$ groups due to $\mathrm{pH}$ effect.

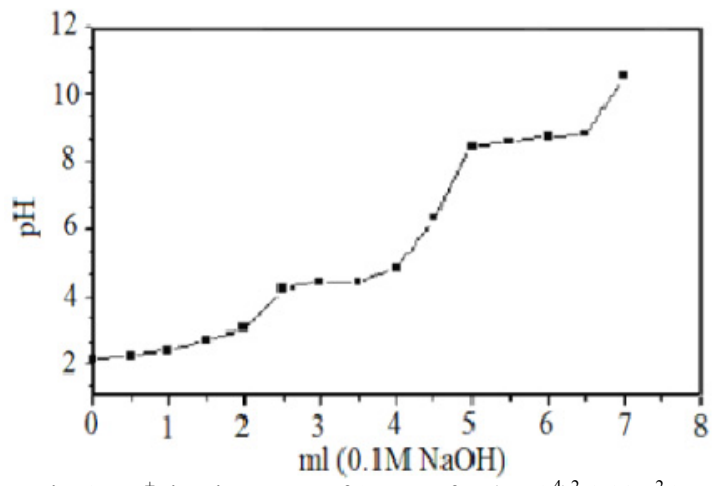

Fig. 3. $\mathrm{Na}^{+}$titration curve of $\theta$-type of $\mathrm{Zr}\left(\mathrm{HPO}^{4}\right)^{2} \cdot 1.88 \mathrm{H}^{2} \mathrm{O}$. 


\section{TG/DTA of $\theta-\operatorname{Zr}\left(\mathrm{HPO}_{4}\right)_{2} \cdot 1.88 \mathrm{H}_{2} \mathrm{O}$}

Thermal analysis of $\theta$-type $\mathrm{Zr}\left(\mathrm{HPO}_{4}\right)_{2} \cdot 1.88 \mathrm{H}_{2} \mathrm{O}$ is shown in Fig. 4 and was carried out at temperature range $\sim 25-800 \mathrm{C}^{\circ}$, in air atmosphere, the heating rate was $10 \mathrm{C} / \mathrm{min}$. The thermal decomposition exhibits two weight loss stages, the loss of water of hydration followed by $\mathrm{POH}$ groups condensation.

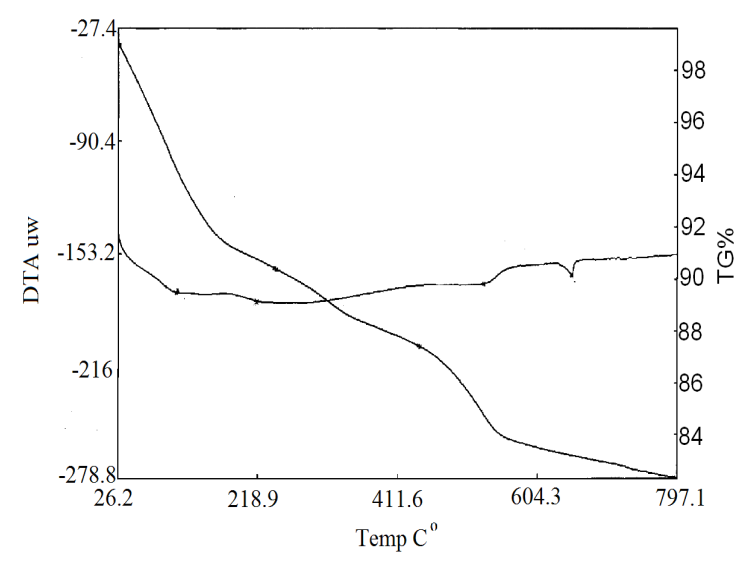

Fig. 4. TG/DTA pattern of $\theta$-type of $\mathrm{Zr}\left(\mathrm{HPO}_{4}\right)_{2} .1 .88 \mathrm{H}_{2} \mathrm{O}$.

The first stage is accompanied by weight losses equal to $16.52 \%$ up to $210 \mathrm{C}^{\circ}$ which have been attributed to the loss of water of hydration. The second stage in the region $320-650 \mathrm{C}^{\circ}$ ascribed to the loss of the structure water due to $\mathrm{POH}$ groups condensation. The weight losses were $5.65 \%$ and final product was the pyrophosphates $\mathrm{ZrP}_{2} \mathrm{O}_{7}$.

Amino acids L-alanine, L-aspargine, L-serine, L-arginine, and proline based $\theta-\mathrm{Zr}\left(\mathrm{HPO}_{4}\right)_{2} \cdot 1.88 \mathrm{H}_{2} \mathrm{O}$ have been synthesized at room and at $60^{\circ} \mathrm{C}$ temperatures. The Loading of the amino acids at $60^{\circ} \mathrm{C}$ found to be less than $30 \%$ for L-arginine, $\theta-\mathrm{Zr}\left(\mathrm{HPO}_{4}\right)_{2}(\arg )_{1.32} . \mathrm{H}_{2} \mathrm{O}$ almost the same for L-proline $\theta-\mathrm{Zr}\left(\mathrm{HPO}_{4}\right)_{2} \quad(\mathrm{prol})_{0.02} \cdot 1.1 \mathrm{H}_{2} \mathrm{O}$ and low for L-aspargine $\theta-\mathrm{Zr}\left(\mathrm{HPO}_{4}\right)_{2} \quad(\operatorname{aspg})_{1.32} . \mathrm{H}_{2} \mathrm{O}$ and L-serine $\theta-\mathrm{Zr}\left(\mathrm{HPO}_{4}\right)_{2}(\mathrm{ser})_{0.39} \cdot 0.5 \mathrm{H}_{2} \mathrm{O}$. However, it was no uptake in the case of $\mathrm{L}$-analine.

Their elemental contents of $\mathrm{C}, \mathrm{H}, \mathrm{N}$ at room temperature have been characterized by elemental $(\mathrm{C}, \mathrm{H}, \mathrm{N})$ and TGA analysis and the results are shown in Table I. The loading of the amino acid found to be dependent on its nature. The resultant amino acids inclusion products were formulated from combination of elemental and thermal analysis and were designated as compounds (I-V) and their water of hydration were calculated from the TG curve, Fig. 5-Fig. 8.

TABLE I: Percent Elements Content (C, N, H) OF Amino Acids

\begin{tabular}{|c|c|c|c|}
\hline Compound & $\mathrm{C}$ & $\mathrm{H}$ & $\mathrm{N}$ \\
\hline (I) $\theta-\mathrm{Zr}\left(\mathrm{HPO}_{4}\right)_{2}$ (anal) 0.0 & nill & nill & nill \\
\hline (II) $\theta-\mathrm{Zr}\left(\mathrm{HPO}_{4}\right)_{2}(\operatorname{aspg})_{0.54} 1.63 \mathrm{H}_{2} \mathrm{O}$ & 10.6 & 2.0 & 6.18 \\
\hline (III) $\theta-\mathrm{Zr}\left(\mathrm{HPO}_{4}\right)_{2}(\mathrm{ser}) 0.39 .0 .5 \mathrm{H}_{2} \mathrm{O}$ & 8.27 & 1.6 & 3.2 \\
\hline (IV) $\theta-\mathrm{Zr}\left(\mathrm{HPO}_{4}\right)_{2}(\arg )_{1.32} . \mathrm{H}_{2} \mathrm{O}$ & 22.8 & 4.78 & 15.97 \\
\hline
\end{tabular}

\section{E. TGA of Amino Acids Inclusion Products}

The thermal analysis used in this and other studies found to be a good tool for characterization of organic inclusion products of M(IV) phosphates with good accuracy in the range of $2 \%$ [5], [6], [19].

TG/DTA, of aspargine inclusion product $\theta-\mathrm{Zr}\left(\mathrm{HPO}_{4}\right)_{2}$ (aspg) $)_{0.54} 1.63 \mathrm{H}_{2} \mathrm{O}$ compound (II) is shown in (Fig. 5).

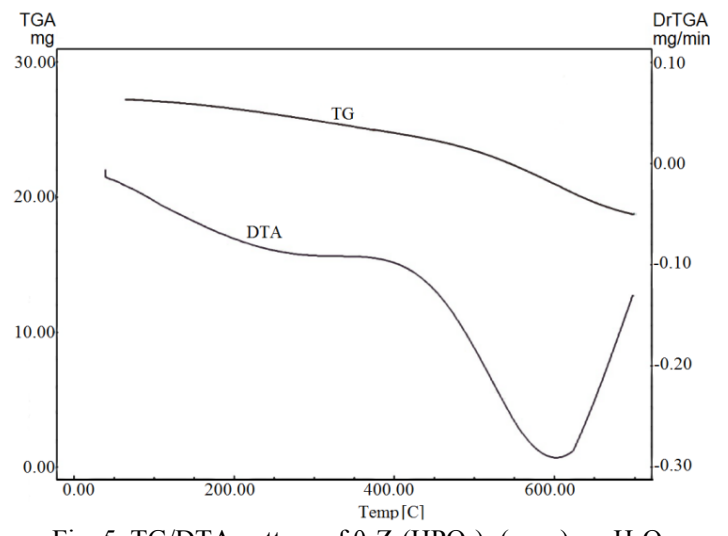

Fig. 5. TG/DTA pattern of $\theta-\mathrm{Zr}\left(\mathrm{HPO}_{4}\right)_{2}(\operatorname{aspg})_{1.32} \cdot \mathrm{H}_{2} \mathrm{O}$.

It can be seen that thermal decomposition found to occur in two stages. The loss of water of hydration initiated at $\sim 65^{\circ} \mathrm{C}$ up to $160^{\circ} \mathrm{C}$, followed by de-intercalation, decomposition of the organic compound and $\mathrm{POH}$ groups condensation. The thermal decomposition of the organic compound found to superimpose to that of the $\mathrm{POH}$ groups condensation. The weight loss was accompanied by endothermic broad peak centered at $\sim 270^{\circ} \mathrm{C}$. Total weight loss found to be $31.15 \%$.

Fig. 6 shows TG /DTA of inclusion product, $\theta$ $\mathrm{Zr}\left(\mathrm{HPO}_{4}\right)_{2}(\mathrm{ser})_{0.39} \cdot 0.5 \mathrm{H}_{2} \mathrm{O}$, compound (III). The thermal decomposition found to be occurred in two stages. Compared with Fig. 5, the loss of water of hydration initiated at $\sim 60^{\circ} \mathrm{C}$ up to $150^{\circ} \mathrm{C}$ and followed by de-intercalation, decomposition of the organic compound and $\mathrm{POH}$ groups condensation, this is mainly due to the $\mathrm{POH}$ groups condensation started at about $300{ }^{\circ} \mathrm{C}$. The thermal decomposition of the organic compound found to superimpose to that of the $\mathrm{POH}$ groups condensation. The weight loss was accompanied by two endothermic broad peak centered at $200,500^{\circ} \mathrm{C}$. Total weight loss found to be $16.45 \%$.

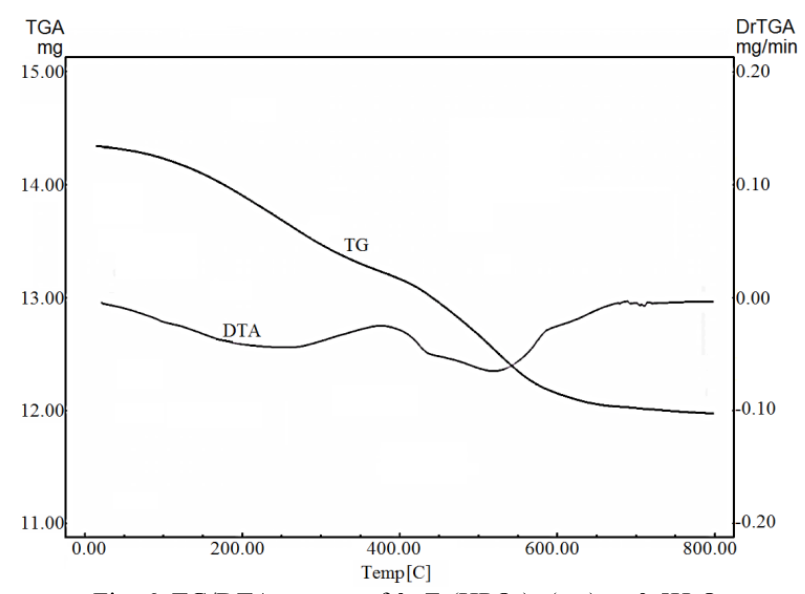

Fig. 6. TG/DTA pattern of $\theta-\mathrm{Zr}\left(\mathrm{HPO}_{4}\right)_{2}(\mathrm{ser})_{0.39} .0 .5 \mathrm{H}_{2} \mathrm{O}$.

TG/DTA pattern of inclusion product, $\theta-\mathrm{Zr}\left(\mathrm{HPO}_{4}\right)_{2}(\arg )_{1.32} \cdot \mathrm{H}_{2} \mathrm{O}$, compound (IV) is shown in Fig. 7. From the figure we can see that the loss of water of hydration initiated at $\sim 60^{\circ} \mathrm{C}$ up to $150^{\circ} \mathrm{C}$ and followed by de-intercalation, decomposition of the organic compound and $\mathrm{POH}$ groups condensation. The thermal decomposition of the organic compound found to superimpose to that of the $\mathrm{POH}$ groups condensation. The weight loss was accompanied by broad endothermic peak centered at $270^{\circ} \mathrm{C}$ 
which very similar to that of $\theta-\mathrm{Zr}\left(\mathrm{HPO}_{4}\right)_{2}(\operatorname{aspg})_{0.54} .1 .63$ $\mathrm{H}_{2} \mathrm{O}$. Total weight loss found to be $50.07 \%$ which higher than that of $\theta-\mathrm{Zr}\left(\mathrm{HPO}_{4}\right)_{2}(\operatorname{aspg})_{0.54} .1 .63 \mathrm{H}_{2} \mathrm{O}$ and $\theta-\mathrm{Zr}\left(\mathrm{HPO}_{4}\right)_{2}$ (ser) $)_{0.39} \cdot 0.5 \mathrm{H}_{2} \mathrm{O}$.

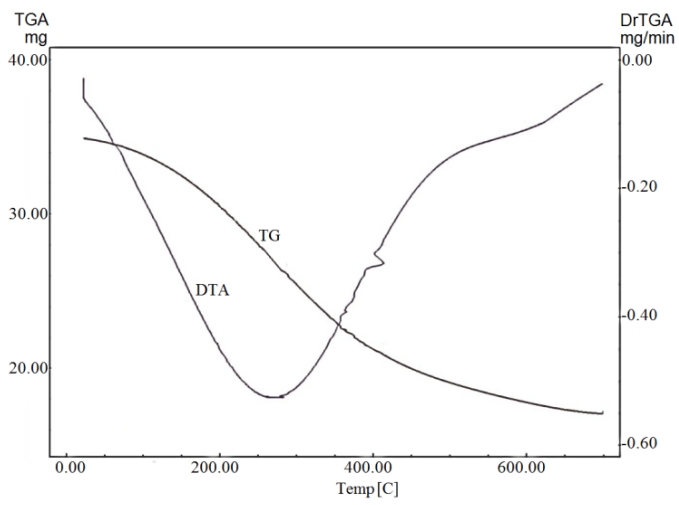

Fig. 7. TG/DTA pattern of $\theta-\mathrm{Zr}\left(\mathrm{HPO}_{4}\right)_{2}(\arg )_{1.32} \cdot \mathrm{H}_{2} \mathrm{O}$.

Fig. 8 shows TG/DTA pattern of inclusion product, $\theta$ $\mathrm{Zr}\left(\mathrm{HPO}_{4}\right)_{2}($ prol $\left.)\right)_{0.02} \cdot 1.1 \mathrm{H}_{2} \mathrm{O}$ compound $(\mathbf{V})$, as shown in Fig. 8. The loss of water of hydration initiated at $\sim 65^{\circ} \mathrm{C}$ upto $170^{\circ} \mathrm{C}$ and followed by de-intercalation, decomposition of the organic compound and $\mathrm{POH}$ groups condensation. The thermal decomposition of the organic compound found to superimpose to that of the $\mathrm{POH}$ groups condensation. The weight loss was accompanied by two broad endothermic peaks centered at $200,600^{\circ} \mathrm{C}$. Total weight loss found to $13.04 \%$.

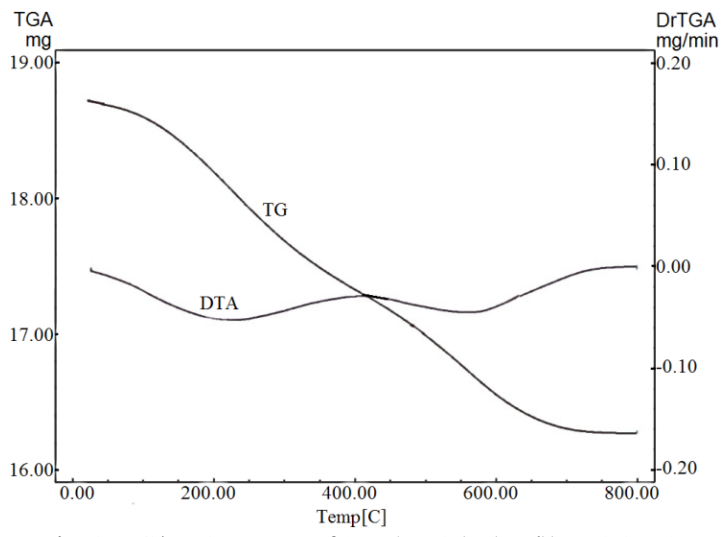

Fig. 8. TG/DTA pattern of $\theta-\mathrm{Zr}\left(\mathrm{HPO}_{4}\right)_{2}($ prol $\left.)\right)_{0.02} \cdot 1 \cdot 1 \mathrm{H}_{2} \mathrm{O}$.

\section{CONCLUSION}

The FT-IR spectra is a key tool to detect the presence of water molecules as well as to investigate the H-bonds in layered M(IV) phosphate. In this study, we reveal that $\theta$-type zirconium phosphate has a tendency to intercalate basic amino acids with good loading. The loading found to be dependent on the nature of the amino acid and the lower loading of proline can be attributed to covering effect [1], [10]. The thermal behavior of the investigated materials found to follow the same trend of that observed for inclusion organic products of tetravalent metal phosphates. The $\mathrm{C}, \mathrm{H}$, $\mathrm{N}$ and TGA analysis were a good tool for the formulation of the end products. Future work will be carried on the protein, encapsulation via direct ion exchange with $\theta$-type zirconium phosphate and the controlled release studies using $\mathrm{pH}$ changes.

\section{ACKNOWLEDGEMENT}

To Tripoli University, Department of Chemistry, faculty of science for providing facilities to this research, to Industrial Research Centre, Tripoli, to Adel Bayuomi Institute of Mineral resources, Cairo, Egypt for providing facilities for TGA, FT-IR and elemental C,H,N.

\section{REFERENCES}

[1] S. K. Shakshooki, N. Naqvi, J. K. Kowaleczyk, S. Khalil, M. Rais, and F. Tarish, "Mixed insoluble acid salts of tetravalent metals: II. Effect of composition on ion exchange properties of amorphous zirconium-titanium phosphate," J. Reactive Polymer, vol. 7, pp. 221-226, January 1988.

[2] A. Clearfield, Inorganic Ion Exchange materials, 1st. ed., CRC Press, Bocca Raton, USA: Flurida, 1982, ch. 1, pp. 6-74.

[3] A. Clearfield and J. A. Stynes, "The preparation of crystalline zirconium phosphate and some observation on its ion exchange behavior," J. Inorg. Nucl. Chem., vol. 26, pp. 117-129, January 1964.

[4] J. Xiao, J. Xu, Y. Wu, and Z. Gao, "Preparation and properties of zirconia-pillared zirconium phosphate and phenylphosphate," Appl. Catal., vol. 181, pp. 313-322, May 1999.

[5] A. Diaz, A. David et al., "Nanoencapsulation of Insulin into Zirconium Phosphate for Oral Delivery Applications," Biomacromol., vol. 9, pp. 2465-2470, September 2010.

[6] A. Diaz, V. Saxena, J. Gonzalez, A. David, B. Casanas, C. Carpenter, J. D. Batteas, J. Colon, A. Clearfield, and M. Hussain, "Zirconium phosphate nano-platelets: a novel platform for drug delivery in cancer therapy," Chem. Commun., vol. 48, pp. 1754-1755, 2012.

[7] A. Dyer and J. A. Gill, "Studies on crystalline zirconium phosphate-III: Self diffusion of sodium ion into monosodium forms of crystalline zirconium phosphate," J. Inorg. Nucl. Chem., vol. 39, pp 665-668, 1977.

[8] G. Alberti, U. Costantino, and J. S. Gill, "Crystalline insoluble acid salts of tetravalent metals: XXVII. Preparation and main ion exchange properties of highly hydrated zirconium bis monohydrogen orthophosphate," J. Inorg. Nucl. Chem., vol. 38, pp. 1733-1739, 1976.

[9] G. Alberti, M. G. Bernasconi, and M. Casciola, "Preparation of $\gamma$-zirconium phosphate microcrystals with high degree of crystallinity and proton conductivity of their hydrogen and ammonium forms," Reactive Polymers, vol. 11, pp. 245-252, 1989.

[10] A. Clearfield, Inorganic Ion Exchange materials, 1st. ed., CRC Press, Bocca Raton, USA: Flurida, (1982), ch. 3, pp. 111-132.

[11] L. Szirtes, J. Megyeri, E. Kuzmann, and Z. Klencser, "Electrical conductivity of transition metal containing crystalline zirconium phosphate materials," Solid State Ionics., vol. 145, pp. 257-260, December 2001.

[12] P. Giannocaro, M. Gargano, A. Fanizi, C. Ferragina, and M. Aresta, "Rh-ions and Rh-complexes intercalated in $\gamma$-titanium or $\gamma$-zirconium hydrogen phosphate as highly efficient catalysts for arene hydrogenation," Appl. Catal A Gen., vol. 284, pp. 77-83. April 2005.

[13] G. Alberti, F. Cherubini, and R. Palombari, "Amperometric solid-state sensor for NO and NO 2 based on protonic conduction," Sensors and Actuators, vol. 37, pp. 131-134, Decmber 1996.

[14] G. Alberti, M. G. Bernasconi, U. Costantino, and G. S. Gill., "Crystalline insoluble acid salts of tetravalent metals: XXVII. Ion exchange of trivalent cations on ionic forms of crystalline zirconium phosphate with large interlayer distances," J. Chromatog., vol. 132, pp. 477-484, February 1977.

[15] T. Kijima, S. Ueno, and M. Goto, "Uptake of amino-acids by zirconium phosphates. Part 2. Intercalation of L-histidine, L-lysine, and L-arginine by $\alpha$-zirconium paragra-phphosphate," Chem. Soc. Dalton Trans, pp. 2499-2503, 1982.

[16] T. Kijima and S. Ueno, "Uptake of amino-acids by zirconium phosphate. Part 3. Intercalation of L-histidine, L-lysine, and L-aginine by $\gamma$-zirconium phosphate," Chem. Soc. Dalton Trans, pp. 61-65, 1986.

[17] U. Costantino et al., "Amino acids derivatives of layered zirconium phosphates- $\alpha$-Zirconium L-(+)-Serinephosphate and Zirconium L-(+)-Serinephosphate Phosphates," European J. of Inorg. Chem., pp. 1447-1452, October 1998.

[18] R. Q. Zeng, X. K. Fu, and X. B. Yang, "Intercalation of basic amino acids into layered zirconium proline- $N$-methylphosphonate phosphate," Chemical Papers, pp. 674-681, October 2011.

[19] H. Hayashi, K. Torli and S. J. Nakat, "Hydrothermal treatment and strontium ion sorption properties of fibrous cerium (IV) hydrogenphosphate," J. Mater. Chem., vol. 7, pp. 557-562, 1997. 


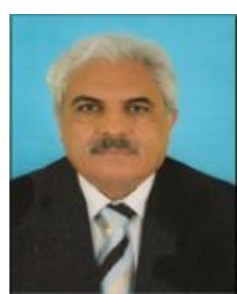

Sadek Shakshooki is a $\mathrm{Ph} . \mathrm{D}$. Currently he is a professor in Department of Chemistry, Faculty of Sciences, University of Tripoli, Libya.

In 1971, he obtained his Ph.D. in inorganic chemistry, Bristol School of Chemistry, Bristol University, Bristol, Uk. In 1975-1978, He was the dean College of Pharmacy, University of Tripoli, Libya. In 2000, He awarded as outstanding staff member and researcher of Faculty of Science, from University of Tripoli; given for $1^{\text {st }}$ time.

He has more than 140 publications in international journals, local and international conferences.

His research interest includes metal complexes, desalination, inorganic ion-exchangers of tetravalent metal phosphates, their pelllicular membranes, intercalation, inclusion of some heterocyclic compounds into layered and glassy materials, proton conductance, inorganic membrane-membrane composites, pillared materials. Established three novel methods for crystallization of glassy and amorphous tetravalent metal phosphates to their layered materials. He established novel methods for pellicular membranes And fibrous membranes of tetravalent metal phosphate.

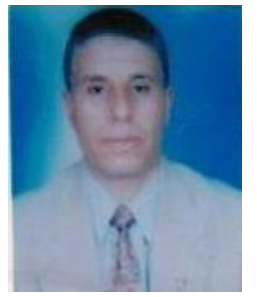

Abdurrahman M. Rhuma is a Ph.D. Currently he is an lecturer in Department of Chemistry, Faculty of Science, University of Tripoli, Libya,

In 2007, he obtained his Ph.D. in Biochemistry, in De Montfort University, Leceister, UK.. In 1984, he received his BSc in chemistry from University of Tripoli. From 2008 to date he is The Head of Chemistry Department, faculty of Education, University of Tripoli, Libya and the chief editor of the journal of Education.

He has one recent publications: A. Rhuma, R. Jenkins, P. Haris, "Antimicrobial activities of Nigella sativa floral honey towards selected pathogenic and non-pathogenic microorganism," J. of Ed., vol. 7, pp. 12-20.

His research interest includes bioactive compounds analysis, characterizing of antimicrobial and anticancer compounds. Inclusion of heterocyclic and organic compounds into layered materials and protein analysis.

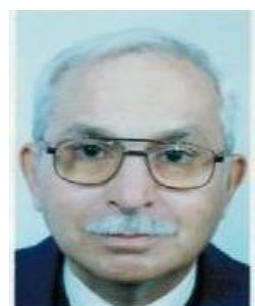

Fadel Siala is a $\mathrm{PhD}$. Currently he is an associate professor in Department of Chemistry, Faculty of Science, University of Tripoli, Libya.

In 1975, He obtained his $\mathrm{PhD}$ in Organic Chemistry. London University, London, UK. In 1987 and 1990 he was the head of Chemistry Departement, Faculty of Science, University of Tripoli, Libya. 